\title{
Homeless Perpetrators and Victims of Crimes: Preliminary Findings of a Research in the Region of Puglia (Italy)
}

\author{
Ignazio Grattagliano ${ }^{1, *}$, Cristian Signorile ${ }^{2}$, Andrea Lisi ${ }^{1}$, Maria Francesca De Rinaldis ${ }^{1}$, \\ Maria Antonietta Montedoro ${ }^{1}$, Giovanni Aliquo ${ }^{3}$, Daniela Poduti ${ }^{3}$, Lucio Palella ${ }^{3}$, \\ Vito Ventrella ${ }^{3}$ and Roberto Catanesi \\ ${ }^{1}$ Department of Criminology and Forensic Psichiatry University of Bari, Italy \\ ${ }^{2}$ Help Center Psychosocial Bari, Italy \\ ${ }^{3}$ Department of Italian Police Railway, Italy
}

\begin{abstract}
The aim of the study is to analyze from a criminological perspective a peculiar case of deviance: that perpetrated by homeless people, defined as "an individuals in a condition of material and immaterial poverty, carrying a complex, dynamic and multiform kind of discomfort".

In collaboration with the Division of the Railway Police of the Regions of Puglia, Basilicata and Molise, 95 homeless were recruited and the incidence of perpetrators and victims of crimes was investigated.
\end{abstract}

Keywords: Homeless, perpetrators, victims, criminology, psychopathology.

\section{INTRODUCTION}

The terms "tramp and homeless" derive from "Birbone" (Bonadonna 2005) and they connote a prejudice more than a neutral definition, because semantically they refer to a criminal and a delinquent person. Other terms identifying this category, such as "clochard, homeless, sans abri, thuisloos, roofless, roaming homeless, hobo", are modern labels used to connote extreme cases of marginalization, on the border of survival. These people live in degraded contexts, like on the streets, and because of this condition, they are exposed to severe risks. Homeless people represent currently an heterogeneous group of people from both an epidemiological and biographical standpoint: this group includes ex-prisoners, psychiatric patients, alcoholics, drug addicts, individuals who have experienced past traumatic experiences within the family or in institutional contexts as well as individuals expelled from the working and productive circuits. The homeless are considered dangerous and deviant people, without a house in the physical and spatial meaning and victims of social alienation and of the deficiency and/or inconsistency of solid relational networks.

The official data reported by the FIO.PSD (Federazione Italiana Organismi per le Persone Senza Dimora - Italian Federation of Agencies for Homeless

*Address correspondence to this author at the Department of Criminology and Forensic Psichiatry University of Bari, Italy; Tel: +39 3356296 185;

Fax: +39 080 5478248; E-mail: ignazio.grattagliano@uniba.it
People) show that the homeless live in conditions of extreme alienation and deterioration of primary and secondary relationships. More specifically, according to this report, the homeless are characterized by the following features:

an acute painful condition, albeit coming transversally from different socio-cultural backgrounds;

a breakdown of the membership to social and territorial networks;

a complex form of discomfort with multiple problematic factors, not necessarily linked causally one to the other;

a degenerative evolution;

in extreme forms, a compromise of the individual's capacity to satisfy basic needs, leading in some cases to death;

from the perspective of those taking care of them, the homeless people appear incapable to become emancipated, even in the presence of wealth and life conditions provided with valid opportunities.

At the European level, the European Federation of National Organizations Working with the Homeless (Feantsa 2005), has classified the homeless people through the ETHOS (European Typology of Homelessness and Housing Exclusion) and has correlated such classification system with a set of 
indicators: the findings highlighted four categories of severe housing exclusion. The first are the Roofless, including people living in the streets or in public spaces or who make use of night shelters; the Houseless, who use homeless hostel, temporary accommodations and transitional supported accommodation; the third group includes the Insecure, who are those staying temporarily with family/friends, with no legal (sub) tenancy or who occupy illegally a land; lastly the Inadequate, including, as the label suggests, people living in inadequate arrangements, such as mobile homes, non-conventional buildings and temporary structures.

Mackenzie e Chamberlain (2003) conceptualize homelessness as a career process and they identify three pathways leading to such condition in adulthood. In the first case, conditions of poverty or accumulating debts cause the slide into homelessness. There is no "in and out" stage in the housing crisis career but a sharp break into homelessness, which becomes a real "way of life". As to the second pathway, this can occur in the presence of a family breakdown: in such cases, the homelessness represents an escape from domestic violence; in such a trajectory, a woman in particular can go though the "in and out" stage, as she can escape and return to the family home a number of times to try to solve family issues. The last pathway takes place during the transition from youth to adult homelessness and it includes people who experience homelessness since adolescence.

Many studies have been conducted in order to understand the incidence of this phenomenon in our country: the estimates vary depending on the research methodology and on the definition of homelessness. In 2012 the ISTAT (the Italian National Institute of Statistics), in collaboration with the Ministry of Work and the FIO.PSD, reported that the estimate of homeless people in Italy was around 50.000 units, with a higher incidence in the North-West regions of the country $(0.35 \%)$, followed by the North-East regions $(0.27 \%)$, the Centre, with an incidence of $0.20 \%$ and lastly the South with an incidence of $0.10 \%$.

One pivotal aspect of homelessness is the loosening of family relationships following a wide range of different events, as for example the individual's intentional choice, rejection or abandonment from the family, or emigration from the country of origin (Nanni 1998; Pinto et al. 2013). For these people it becomes complicated to develop new social bonds, because of the unavailability of "social goods", which usually support the building of new social relationships (Meo 1995).

\section{EPIDEMIOLOGICAL DATA}

\section{Homelessness and Psychiatric Disorders}

Studies conducted by Vazquez, Munoz e Sanz (1997) and by Fichter e Quadflieg (2001) show that a significant percentage of homeless people suffer of psychiatric disorders, at times, in a rather severe form. Compared to the normal population, the homeless are 2.4 times more likely to be affected by a mental disorders on Axis 1: $73.4 \%$ of the homeless individuals who completed the SCID-I fulfilled all the criteria for a diagnosis of the DSM- IV's Axis 1.

Disorders related to the use of substances are the most frequent ones, as they occur in $63 \%$ of the examined homeless individuals (Koegel, Burnam and Farr 1988). In USA, this percentage stands around $31.2 \%$ of the recruited sample; in Australia, $26 \%$ of the homeless people resulted to be dependent from psychotropic substances (Herrman et al. 1989). It is worthy to mention that also mood disorders are prevailing among this population: in Germany the incidence is around 16.3\% (Fichter and Quadflieg 2001), 17\% in Spain (Vazquez et al. 1997), 20.9\% in the USA (Koegel et al. 1988) and 12\% in Australia (Herrman et al. 1989). With respect to the incidence of psychotic disorders, the percentages were the following among each sample: 6.6\% in Germany (Fichter and Quadflieg 2001), 11\% in Spain (Vazquez et al. 1997); $11.5 \%$ in the USA (Koegel et al. 1988) and $18 \%$ in Australia (Herrman et al. 1989). With respect to anxiety disorders, findings are less significant and appear incomplete: in Germany there is an incidence of $11.6 \%$ of these disorders among the sample that was analyzed, while it was of $13.9 \%$ among a USA sample (Koegel et al. 1988).

Findings on the incidence of personality disorders among homeless people are rare and those available are incomplete, due to the difficulty to lead to a reliable diagnosis. In Germany (Fichter et al. 1996), the prevalence of personality disorders among the homeless is about $4.1 \%$. In USA, the percentage of homeless affected by antisocial personality disorders is $20.8 \%$ (Koegel et al. 1988). Lastly, also cases of double diagnoses are frequently reported: for example, among the homeless people living in Munich, double diagnoses have been reported in $53.4 \%$ of the cases examined (Fichter and Quadflieg, 2001). 
Overall, the findings reviewed above show that the most common psychiatric disorders among the homeless are those on Axis I, with a higher incidence among men, compared to women, although depressive disorders show an opposite trend (Smith, North and Spitznagel 1993), with an incidence of $24.7 \%$ among homeless women, against $22.1 \%$ among homeless men (Fichter and Quadflieg, 2001). In the same studies, differences between men and women tend to favor the latter also in the case of the incidence of generalized anxiety disorders (5.7\% among women vs. $0.7 \%$ among men) and Post Traumatic Stress Disorders (30.8\% among women vs. $1.9 \%$ among men) (Smith et al. 1993; Fichter and Quadflieg 2001).

\section{Homelessness and Substance Abuse}

Substance abuse is an increasing phenomenon among the homeless (CNCA, 2005), as it represents on a symbolic level an attempt to find an illusory and transient shelter or refuge for those who are constantly exposed to severe risks on the road. In many cases, homeless people experience drug addiction as a shelter because of its immediate beneficial effects and because it offers an apparent source of support; nevertheless, at the same time, it increases their vulnerability and alienation. Among the beneficial effects of psychotropic substances, there are the reduction of the sense of hunger, the mitigation of the perception of coldness and fatigue, the immediate comfort from physical pain, the possibility to favor the transition to sleep in conditions in which that would be impossible or in which indeed people would keep awake because of the perceived surrounding dangers. Moreover, it is necessary to keep in mind that the consumption of substances is the only way homeless people have to experience pleasure, although such experience is inducted, brief, transient and selfreferential.

The seductive and winning features of psychotropic substances can dim their harmful consequences and the high cost it is necessary to pay to experience a transitory thrill: besides cases of overdose, other boundary cases are becoming increasingly frequent, in which the substance use in combination with other risky conditions related to living on the road can lead to fatal cocktail situations, as for example unperceived freezing, or fights to conquer a place to sleep.

According to the statistics, the most frequently legal and illegal substances used by the homeless are: alcohol, mostly used by "clochards" an illegal immigrants, heroine, used by homeless drug-addicted, free-base cocaine (crack), most frequently used by ethnic minorities; ketamine, used by "punkabestia"; lastly, combinations of drugs and psychotropic drugs together with alcohol (wine and beer), which occur most frequently among homeless people with psychiatric disorders. Although the association between drug consumption and homeless life is empirically demonstrated, it is not possible to infer the way of causation: it is true that substance abuse can be responsible for the worsening of life conditions, but also the other way round is plausible, that is that social alienation may induce homeless people to turn to substance consumption (CNCA, 2005).

In support of the bidirectional hypothesis, some authors (MacKenzie and Chamberlain, 2003) have reported only few cases for whom the abuse of alcohol and drugs led to homelessness; on the contrary, they reported that the problems of drug-addiction and alcohol abuse emerged after the beginning of homelessness. Moreover, the difficulty to overcome such condition may induce depressive states which may favor the consumption of legal and illegal drugs in order to find a temporary relief. This may be the case, for example, of immigrants who fail to fulfill their plans and experience consequently a sense of failure and loneliness, or of people who lose their jobs and homes and experience the disruption of their affective relationships (CNCA, 2005). Therefore, the consumption of drugs is both the cause and the consequence of social alienation (Carpentier 2002; Marvelli et al. 2013).

\section{Homelessness and Perperators and Victims of Crimes}

Since the end of the XIX century and at the beginning of the $\mathrm{XX}$ one, in the collective imagination there was a shared idea that illegality was correlated to homelessness (London 1907; Anderson 1923). Fisher (1992) reported that homeless people were those with the highest percentage of arrests and imprisonments compared to the normal population. The same author identified four different roles of homeless people in criminal activities: 1. a transient condition of homelessness within a wide criminal career: these people are characterized by antisocial personality and addiction to drugs; thus, incarcerations are a consequence of a chronic deviant behavior; 2. criminal activities such as minor stealing, drug pushing and prostitution, which are the means to enhance the insufficient resources to live. The implementation of 
specific services would discourage these deviant social behaviors; indeed, for these people, displaying deviant behaviors, such as squatting abandoned buildings or parked vehicles, seems to be a specific device to induce police to arrest them, in order to obtain a temporary shelter in prison; 3. people with reduced mental capacities, as a consequence of psychotic traits and recurrent violent behaviors: in such cases, the disorientation induced by drug consumption or mental illness can attract the police's attention and lead these people to incarceration. As a fourth group, there is a significant percentage of drug pushers living among homeless people. It is highly improbable that these pushers are the big drug traffickers, because they are very poor and do not have the considerable amount of money available for this activity. In such cases, the reasons of incarceration are the possession of drugs and the illegal behaviors finalized to obtain money necessary to buy drugs (Ficher 1992). Grimshaw (2002) classifies the homeless' crimes in those committed for survival reasons (that is, those committed for necessity, in reaction to poverty, such as mendicity, prostitution, bag-snatching, shoplifting and stealing); crimes derived from the life condition (crimes committed in reaction to the stress related to the homelessness condition, such as consumption of illegal drugs or minor forms of violence) and lastly crimes deriving from stigmatizing (these crimes imply an enhanced attention of police towards the homeless because of the growing stigma of public opinion). Other studies have investigated a classic issue of interest for criminological and psychiatric-forensic sciences: the relation between mental illness, criminality and homelessness (Martell, Rosner and Harmon 1995; McNiel, Binder and Robinson 2005). Individuals with mental illness, with one or two diagnoses (one or both of a psychiatric nature) perpetrate minor crimes and their arrests are often the ways through which the police can allow them to have access to medical and psychiatric services (Hewitt 1994). In a study investigating the episodes of detention in the first months of the 2000 in San Francisco, the authors (McNiel et al. 2005) investigated the relation between homelessness, incidence of psychiatric diseases, violence and the length of incarceration: findings showed that the majority of incarcerated people, arrested because of stealing and robbery that were affected by a mental disease were also homeless $(75 \%$ with a single diagnosis and $26 \%$ with double diagnoses); moreover the severity of the disease increased the risk of recidivism. From a criminological perspective, the homeless affected by a mental disease should be the target of intervention in order to prevent their involvement in criminal activities. The crimes most frequently committed by this category of homeless are stealing and robbery, while rapes and homicides are less frequent (Snow, Baker and Anderson 1989; Martell 1991; Richman, Convit and Martell, 1992; Fisher et al. 2008). Among the youngest homeless with mental illness, the most frequent crime is prostitution (1/4), followed by drug pushing (Greene, Ennett and Ringwalt 1999); moreover, the incidence of crimes increases among youth at the time they leave home (McCarthy and Hagan 1991; Greco, Curci and Grattagliano 2009). Tanner and Wortley (2002) report that youth has the highest incidence of all types of crimes compared to the normal population and that (young) women have the same likelihood to commit a crime compared to men.

A further issue requiring attention is that incarceration is a considerable risk factor for homelessness. Empirical findings (Zorzi et al. 2006) show that individuals who undergo prolonged detention by the time they finish serving their time in prison, can end up finding themselves isolated from their families and from their social background and may slide into homelessness. Also the opposite could be true (Mental Health Policy Research Group, 1998), as homelessness is a precipitant condition towards incarceration. Empirical evidence shows that $77 \%$ of the homeless experienced at least one incarceration (Gardiner and Cairns 2002), which increases their likelihood to undergo a preventive detention and to plead guilty later on (Calgary: Clarke and Cooper 2000). Moreover, it has been shown that those who do not have a stable home are more frequently kept in prison without bail, in order to avoid the risk that they will not appear in court (Eberle et al. 2001).

The complex relationship between crime and homelessness in which imprisonment is considered a predisposing condition towards homelessness, has been confirmed also by many studies conducted in Wales and in England (Shelter and Cymru 2004). In conclusion, individuals who have been incarcerated are exposed to a higher risk of recidivism, social alienation and homelessness, compared to those who have never experienced prison (Allgood, Moore and Warren 1997).

As a confirmation, a study conducted in New York City demonstrated that those who were homeless before incarceration remained in such condition also after they had served their time in prison (Metraux and Culhane 2004). For such reason, prison has been 
considered as a risk factor for homelessness and the likelihood of not having a house available after the detention, increases the risk of recidivism (Laberge 2000).

With respect to those homeless victims of crimes, this may be a logic consequence of being more exposed to risks, compared to the normal population (Brassard and Cousineau 2000). Among the main risk factors, there are: the unavailability of shelters and homeless hostels having a protective function; attending areas with high rates of criminality; being involved in at risk activities; mental illness and substance abuse. There seems to be a bidirectional link between being victimized and homelessness: on one side, being victimized is a predisposing and precipitant condition towards homelessness; on the other side, living on the road increases the risk to be victimized (Simons, Whitbeck and Bales 1989; Hewitt 1994; Ballintyne 1999). A high incidence of PostTraumatic Stress Disorder has been reported among the homeless victims of crimes, as a consequence of the consistent and repeated experience of being victimized (North, Smith and Spitznagel 1994); additionally, the homeless have higher rates of mortality, compared to those of the housed population (Toronto: Hwang 2000; Shapcott 2007). Experiences of being victimized seem to play a central role in the personal history of homeless women, for whom the pathway towards such life condition is often characterized by domestic violence, divorces (Grattagliano 2013), poverty, various types of family difficulties (D'ercole and Struening 1990; Grattagliano et al. 2012), pregnancy in the presence of low income or a violent partner (Bassuk and Weinreb 1993), escapes from violent family contexts with the following loss of a residence (Novac, Brown and Bourbonnais 1996). Findings show that once they lose their residence, women become more exposed to risky situations (Parkinson 2004; Chamberlain, Johnson and Theobald 2007; Murray 2009), ranging from sexual abuse (Novac, Brown and Bourbonnais 1996) and violent sexual assaults perpetrated by strangers in public spaces (Stermac and Paradis 2001; Wenzel, Leake and Gelberg 2001), to treatments for substance abuse or mental illness (D'ercole and Struening 1990). Studies show that there is no gender difference with respect to crimes related to sexual violence, as these occur among both genders more or less with the same percentages (Ambrosio et al. 1992). One study has investigated differences between homeless and housed people as well as possible gender differences with respect to the incidence of physical and sexual violence (Kushelet al. 2003). The findings show that a significant risk factor for being victimized among homeless people is the presence of psychiatric disorders or drug consumption. Family violence has been identified as a risk factor which concurs with others to homelessness, especially among youth (Shapcott 2007). This idea is supported by the "amplifying risk model", according to which adolescents who escape from home in most cases leave disorganized and dysfunctional family contexts, characterized by conflicts, abuses perpetrated by parents or other family members and lack of parental care (Hermen et al. 1997; Tyler, Hoyt and Whitbeck 2000; Solarino et al. 2012; Scorca et al. 2013). Street life seems to amplify the dysfunctional models they have learned at home leading to risky behaviors which move these adolescents away from the possibility to experience healthy relationships and indeed push them towards deviant pathways (Tyler, Hoyt and Whitbeck 2000; Lisi, et al. 2013). Moreover, these adolescents end up re-experiencing on the street and in an amplified way what they have already experienced at home (Patterson, Dishion and Bank 1984; Patterson, Debaryshe and Ramsey 1989; Whitbeck, Hoyt and Yoder 1999). Compared to those who were not, adolescents who were victims of sexual abuse or neglect within the family underwent more severe consequence when they got street-involved: they display behavioral deficits, poor school adjustment, disruptive behavior at school, early pregnancies in school age, repeated escapes, delinquency and prostitution, early drug and illegal substance consumption which can be prolonged up to adulthood, suicide attempts (Brown and Finkelhor 1986; Janus et al. 1987; Beithman et al. 1991; Beithman et al. 1992; Bayatpour, Wells and Holford, 1992; Lisi, et al. 2012). Experiences of being victimized can be considered as a consequence of social alienation (Gaetz 2004), lack of support from social services (Hewitt 1994; Ballintyne 1999), reluctance to report to the police because of the fear of not being trusted and therefore protected (Brassard and Cousineau 2000; Chamberlain, Johnson and Theobald 2007) and lastly of negative attributions and labeling (Wachholz 2005). This latter case is clear in the use of the label "hate crimes", that is, crimes following intense hate (Levin and McDevitt 1999), which are very difficult to handle (Corbi et al. 2012).

\section{The Study}

In light of the theoretical premises described above, the aim of the study was to collect, through an inquiry 
on the local territory, data on the epidemiological profile and criminological information on the condition of homeless people as perpetrators and / or victims of crimes. This category of deviance is considered as "an invisible population".

\section{Sample}

The study was conducted in the region of Puglia with the collaboration of the Division of the PolFer (the Railway Police) of the Regions of Puglia, Basilicata and Molise, on the basis of the review of the literature. It is important to underline that the study is currently being extended to the adjacent regions, in particular Basilicata and Molise.

The sample includes 95 homeless subjects who completed an articulate self-report administered by the operators of the Railway Police together with personnel of the Section of Forensic Criminology and Psychopathology of the University of Bari.

More specifically, the first aim of the study was to investigate the following epidemiological data:

- Gender differences and distribution in the sample;

- $\quad$ Geographic origin;

- $\quad$ Educational level;

- Previous family condition from which the possible triggering event was dependent on;

- The extent to which the homeless condition became chronic;

- Significant relationships concurrent with the homeless condition;

- $\quad$ Contacts with pertaining services.

As to the second aim, we focused on the following criminological aspects:

- The distribution of gender as a function of the types of perpetrators and/or victims of crimes;

- Time placement of the crime of which the homeless was perpetrator or victim.

\section{RESULTS}

\section{The Epidemiological Data}

Our sample had a prevalence of men (65 men; 30 women) (Figure 1). The analysis of the family conditions showed a complex and problematic situations, with the network of relationships characterized by breakups and alienation/loneliness. Indeed, $36 \%$ were either separated, divorced or widowers and $32 \%$ were singles (Figure 2).

\section{Distribution of homeless' gender}

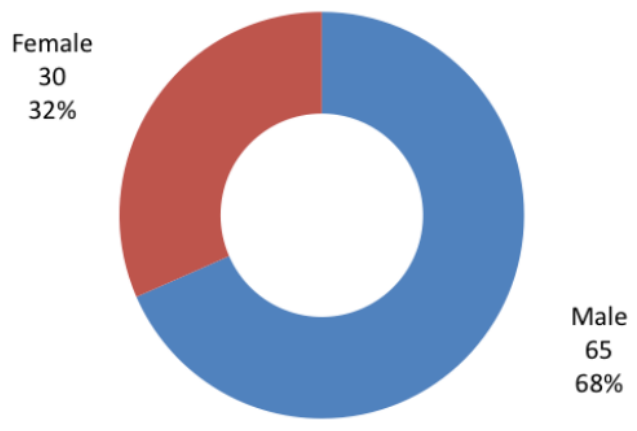

Figure 1: Distribution of homeless' gender.

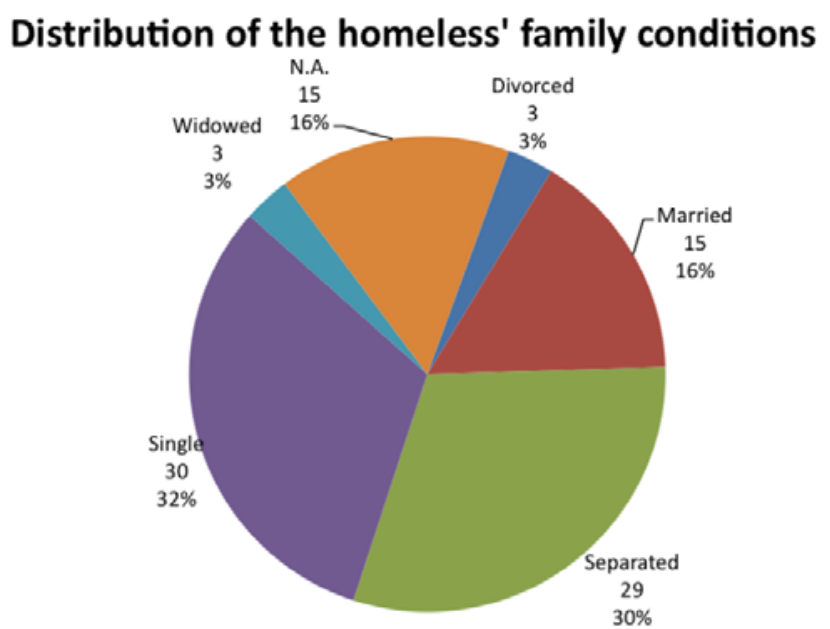

Figure 2: Distribution of the homeless' family conditions.

A consistent portion of the sample was Italian (68 subjects), while the remaining was foreign, mostly coming from East Europe (27 subjects). This finding is inconsistent with those of official reports regarding both the condition of homelessness in the local territory (IPRES, 2013) and on a national level (ISTAT, 2012), according to which most of the homeless are foreign immigrants, the majority of which coming from Romania, Morocco and Tunisia.

Such inconsistency may be a consequence of two aspects: on one side, the methodology implemented in the research may have played a role, as immigrants without a residence permit tend to elude contacts with the local police. Moreover, the peculiar way in which each community of immigrants tends to get organize 


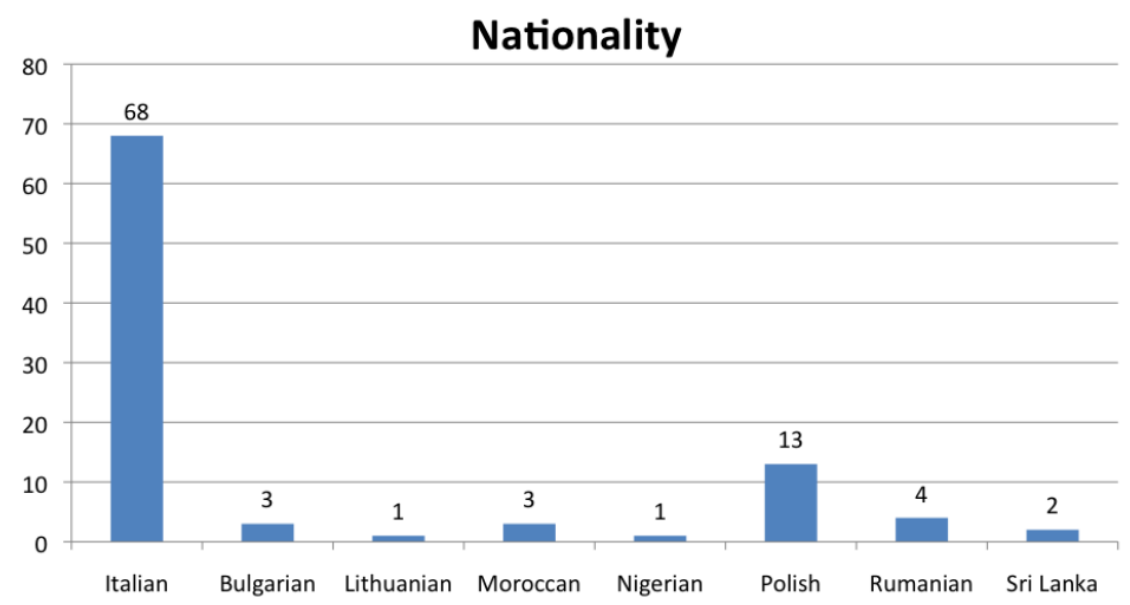

Figure 3: Distribution of homeless' nationality.

and settle in Italy must be taken into account: for example, Rom communities usually arrange camps in the suburbs, instead of living in railway stations, wagons and public parks (Figure 3 ).

The majority of the foreign homeless were in Italy since less than 5 years (93\%) and only $30 \%$ of them had a regular residence permit. This feature seems to reflect the sampling procedure: in fact, those having a residence permit are more likely to have access to daily services and hostels over nights, compared to those who have not, who are forced to live in inadequate contexts, such as railway stations and parks (Figures 4,5 ).

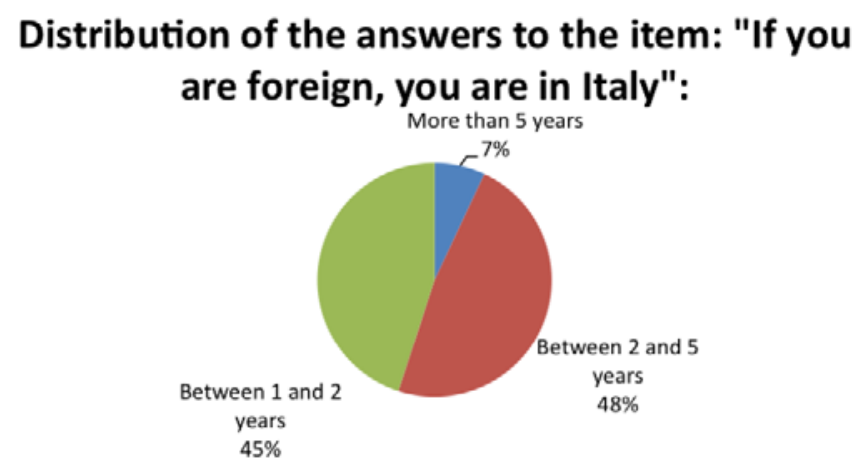

Figure 4: Distribution of the answers to the item: "If you are foreign, you are in Italy".

\section{Distribution of the answers to the item: "If you are foreign, do you have a residence permit?"}

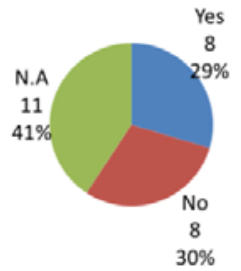

Figure 5: Distribution of the answers to the item: "If you are foreign, do you have a residence permit?"
Educational level was mainly middle-low: only one homeless had a university degree, ten had a high school degree and half of the sample attended only elementary school (46 subjects) (Figure 6). Among the 95 subjects we interviewed, 32 were homeless since one-two years and other 32 since more than five years. Also this result could reflect the sampling procedure: because we focused on the homeless living on the road or in railway stations, we were more likely to recruit the "roofless" (according to the ETHOS classification), who are those individuals experiencing a more severe life breakdown and a chronic homelessness condition (Figure 7).

The main event triggering the slide into homelessness is the job loss (31\%), followed by voluntary removal (15\%), immigration and/or eviction $(10 \%)$ and divorce (9\%) (Figure 8 ). By cross-tabulating the triggering event of homelessness by gender, the results showed that the most frequent triggering event for men was the job loss (26 subjects), while for women it was the loss of the house or removal from the home because of family discomfort (16 subjects) (Figure 9). There was no extremely problematic or atypical family or relational context before homelessness (Figure 10). Instead, it is worthy to underline the quality of the relational and family set-up following homelessness: there was a pronounced alienation characterized by limited and sporadic contacts with family members and/or acquaintances (47 subjects report currently no relationship) (Figures 11, 12). Foreign homeless were characterized by a similar condition, and only $26 \%$ of them had a family member in Italy, although we were unable to point out whether and how they were still in touch with each other (Figure 13, 14).

The connotation of the homeless as "invisible people" is confirmed both by the literature and by our 


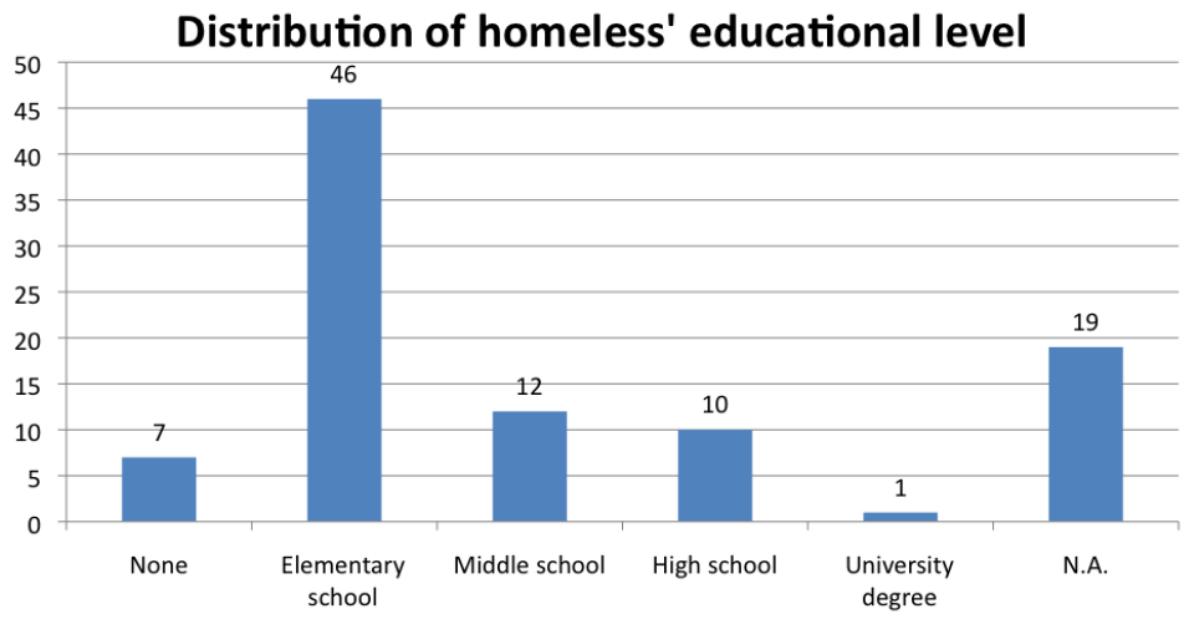

Figure 6: Distribution of homeless' educational level.

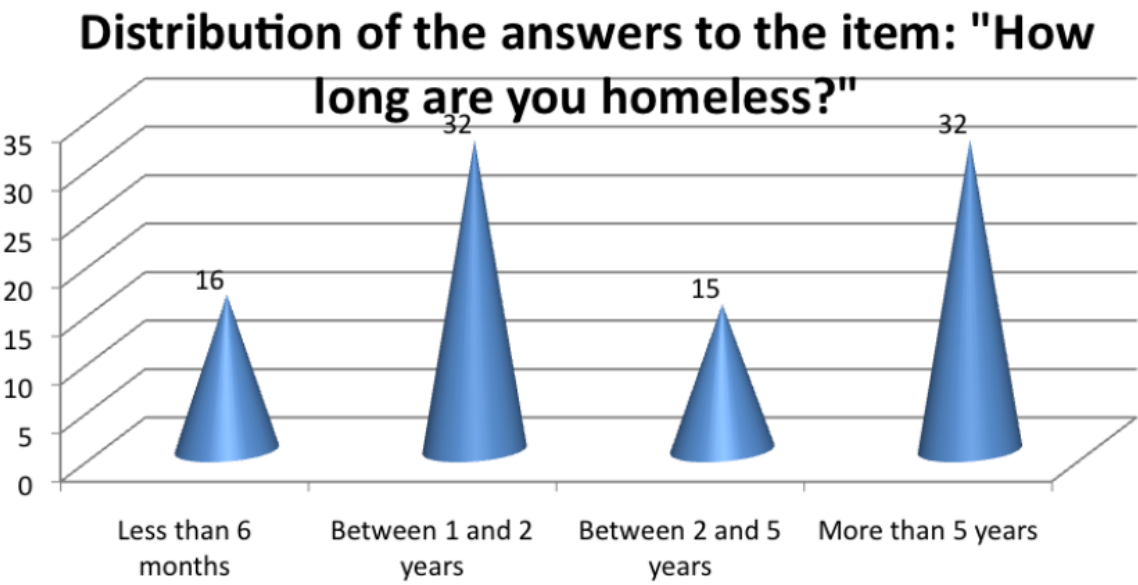

Figure 7: Distribution of the answers to the item: "How long are you homeless?"

\section{Distribution of the events triggering the slide into homelessness}

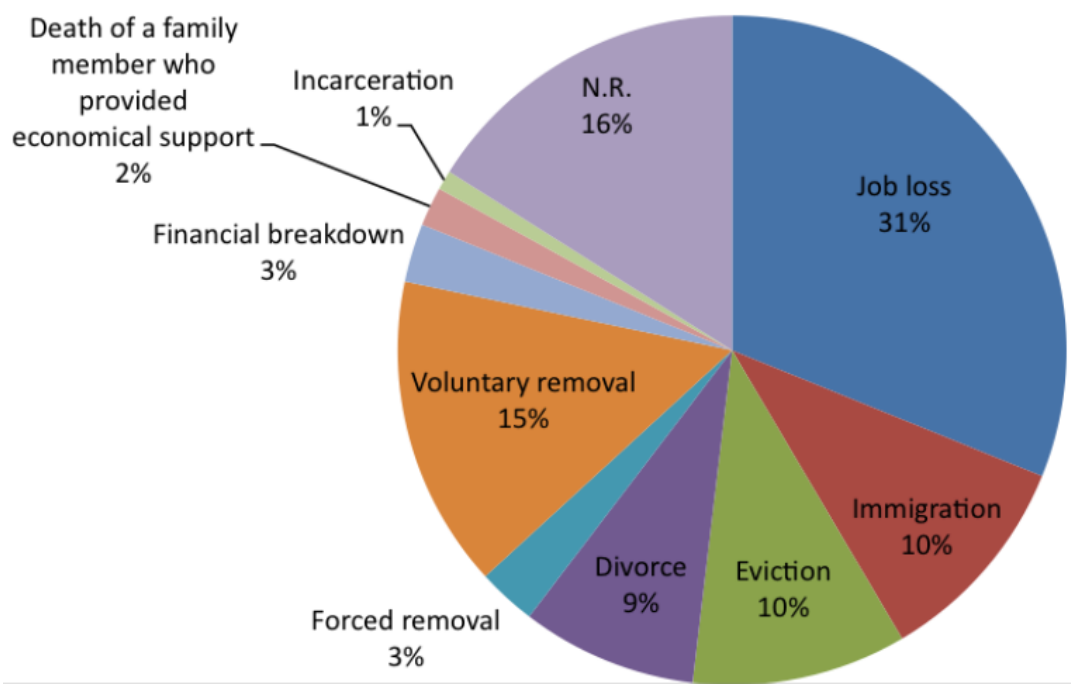

Figure 8: Distribution of the events triggering the slide into homelessness. 
Distribution of events triggering the slide into

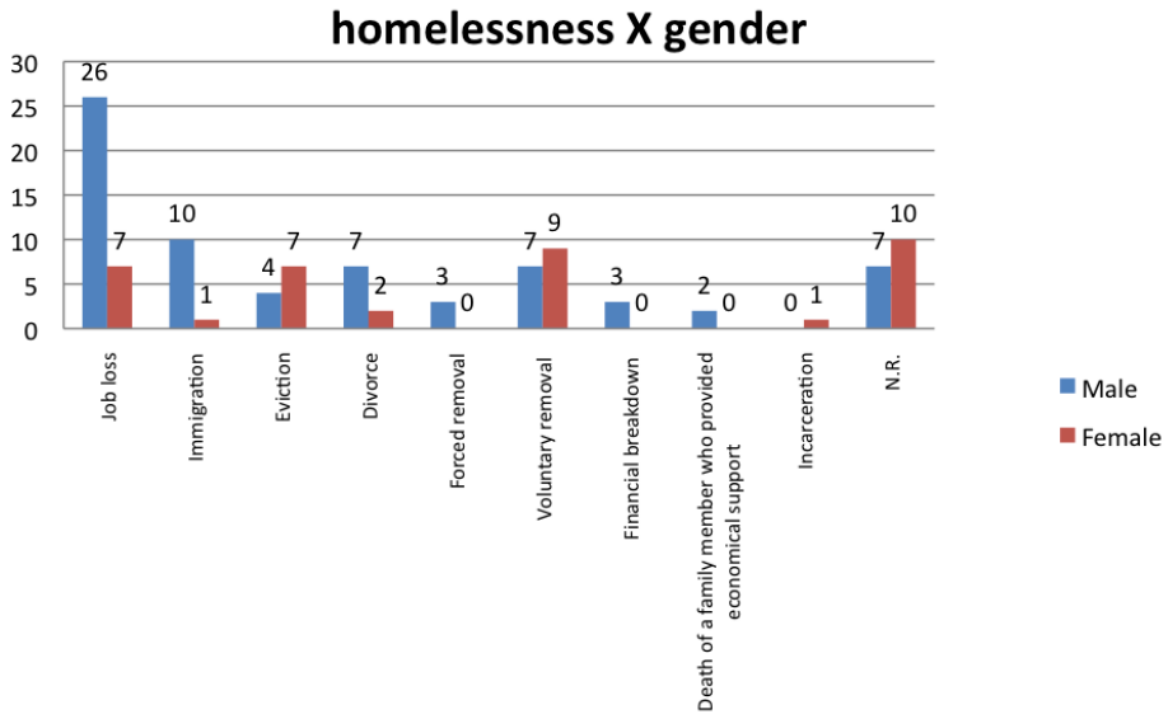

Figure 9: Distribution of the events triggering the slide into homelessness $\mathrm{x}$ gender.

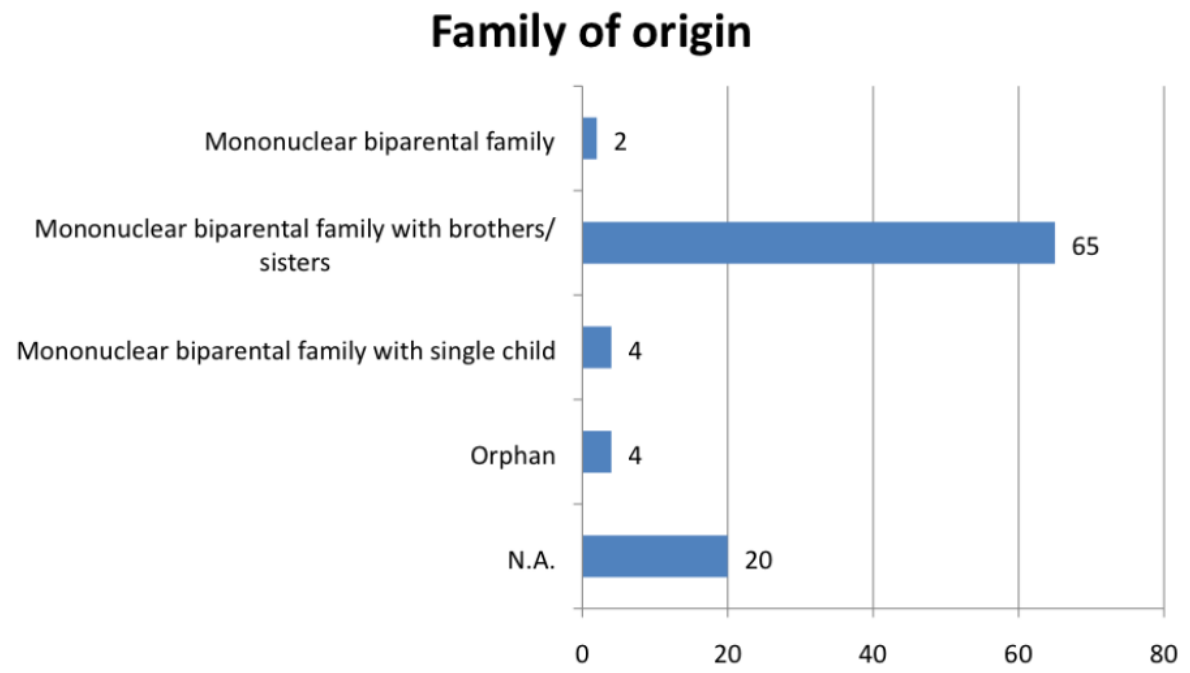

Figure 10: Family of origin.

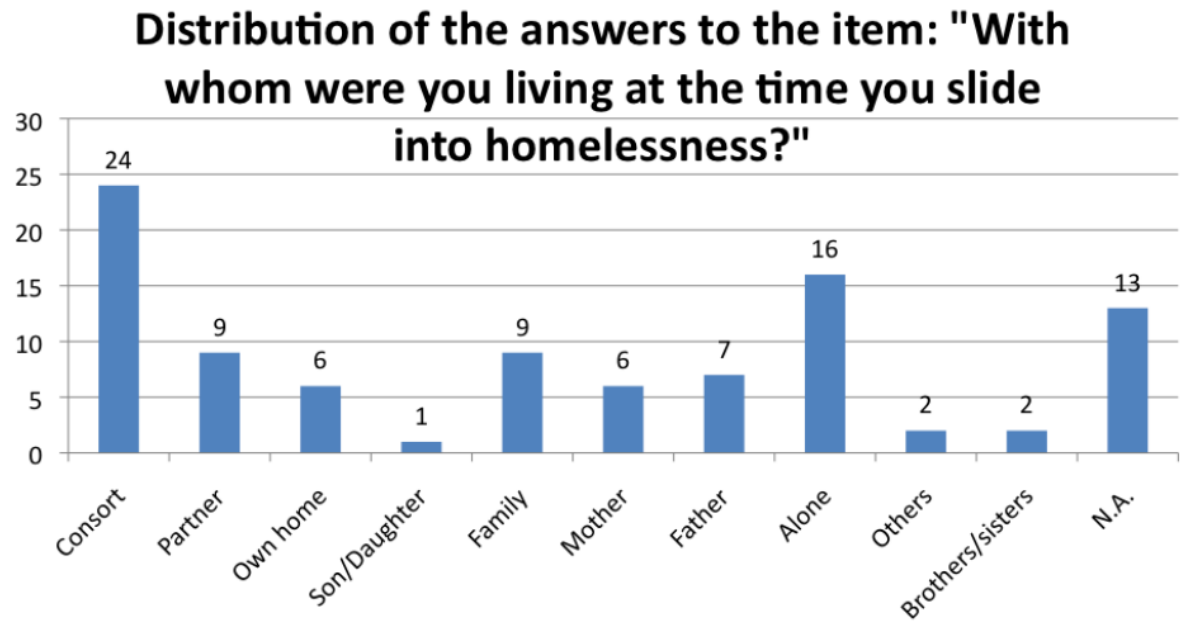

Figure 11: Distribution of the answers to the item: "With whom were you living at the time you slide into homelessness?" 


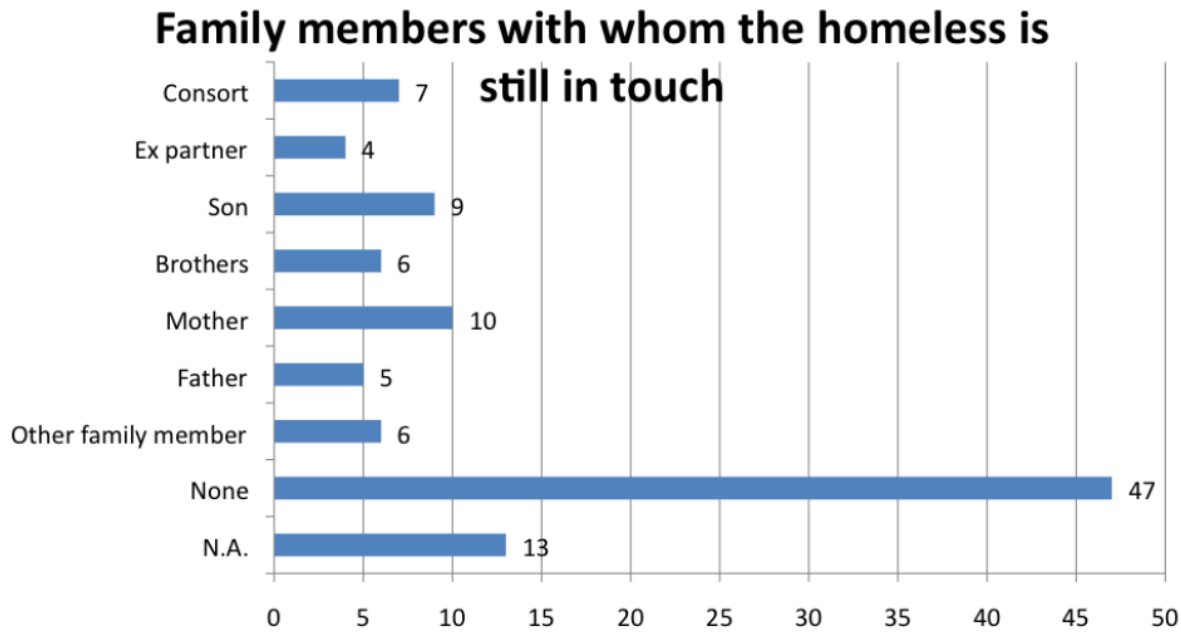

Figure 12: Family members with whom the homeless is still in touch.

Distribution of answers to the item: "If you are foreign, is you family staying in Italy?"

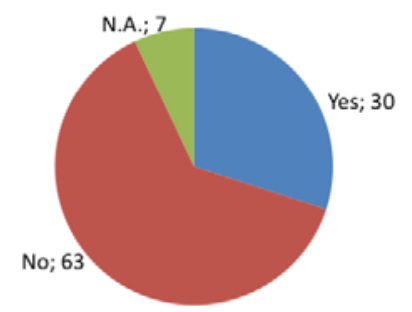

Figure 13: Distribution of answers to the item: "If you are foreign, is you family staying in Italy?"

\section{Distribution of answers to the item: "Which family members are staying in Italy?"}

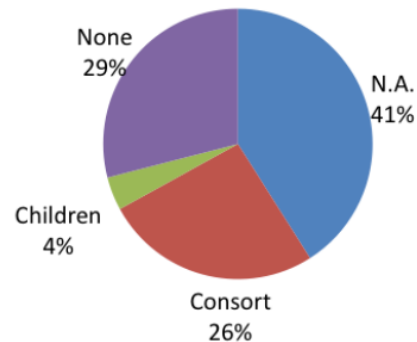

Figure 14: Distribution of answers to the item: "Which family members are staying in Italy?"

findings regarding the contacts with the local assistance services. The number of those who never got in touch with those services is significant (26 over 95 subjects) (Figure 15), as well as the number of those who usually attended structures offering only services for indispensable and material needs, such as meals or night shelters (40 subjects over 95) (Figures 16, 17), which indeed do not provide any kind of psychological service/support. The findings show that it is difficult to establish any kind of relationship with services and workers of daytime centers, as the homeless seem to spend the most of the day in public parks, railway station and on the road (56\%) and they prefer to establish relationships with other homeless (50 subjects over 95 ). Such phenomenon increases the risk of social isolation and loneliness, as well as personal resistances and difficulties towards the opportunity to enrich the personal relational network (Figures 18, 19).

\section{The Criminological Aspects}

The second aim of the study was to investigate the relation between the homeless' epidemiological data and the incidence of being a perpetrator or victim of criminal behaviors. All subjects were resistant to report experiences of being perpetrators and/or victims of crimes, therefore many information were missing. Notwithstanding missing data, the few data available offer interesting hints for understanding this relation. $42 \%$ of the homeless who were interviewed had been involved in criminal behaviors, either as a perpetrator and/or a victim (Figure 20). The cross-tabulation of such frequency by gender, shows results inconsistent with those reported in previous studies: our results show that men have been mainly involved as perpetrators (16 subjects), women either as perpetrators or victims (8 subjects) and, lastly, as the most relevant result, the majority of the subjects (55 men and women) had never been involved in criminal behaviors, either as a perpetrator or as a victim (Figures 20, 21).

A fine-grained analysis to the types of crimes perpetrated shows that the most frequently reported ones are those against properties and people, with some gender differences depending on when the crime 


\section{Distribution of services with which the homeless}

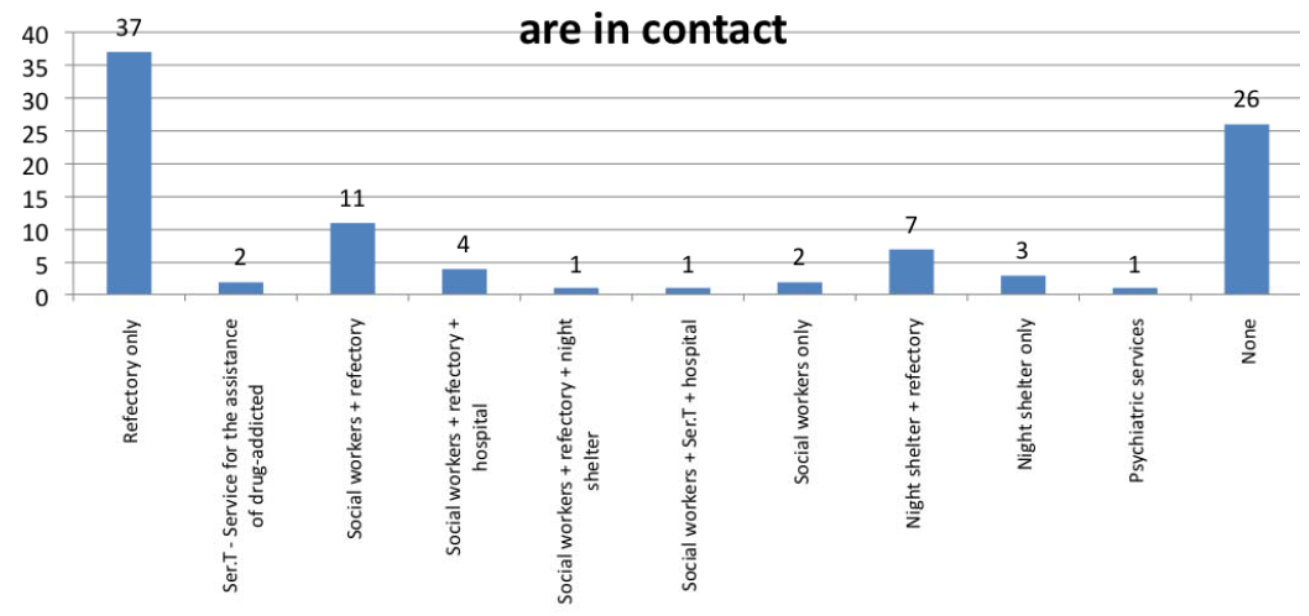

Figure 15: Distribution of services with which the homeless are in contact.

\section{Distribution of the main habits for board and lodging}

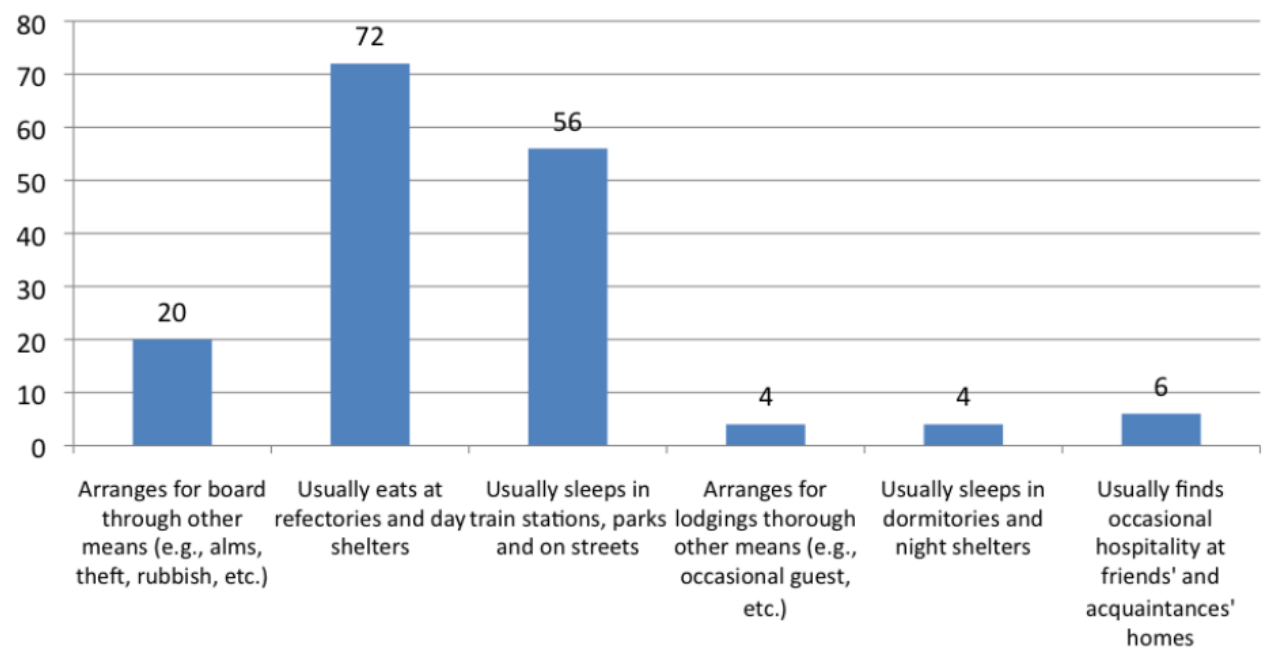

Figure 16: Distribution of the main habits for board and lodging.

\section{Distribution of the main habits regarding day activities}

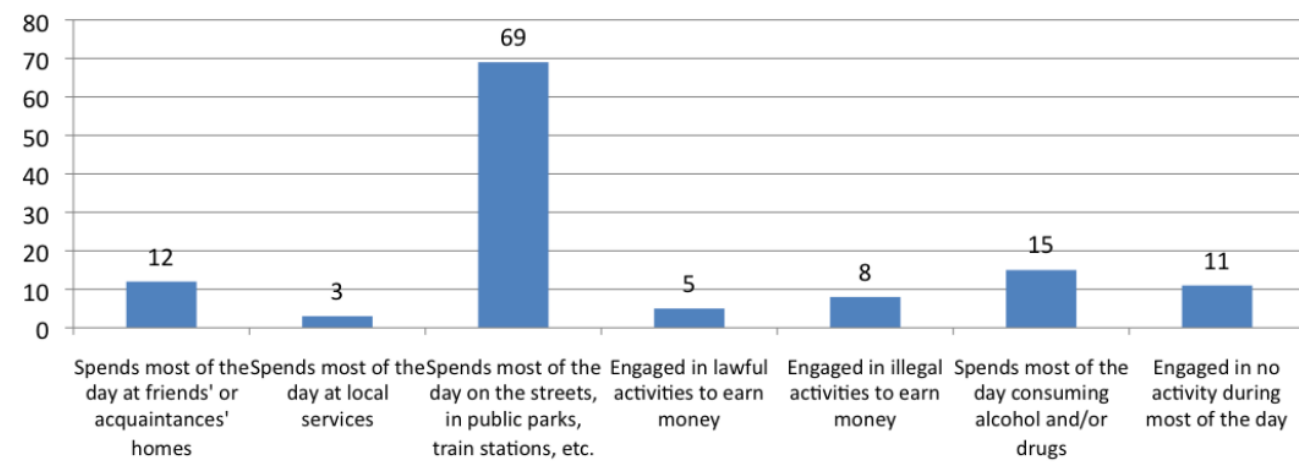

Figure 17: Distribution of the main habits regarding day activities. 
Distribuction of the main relational habits

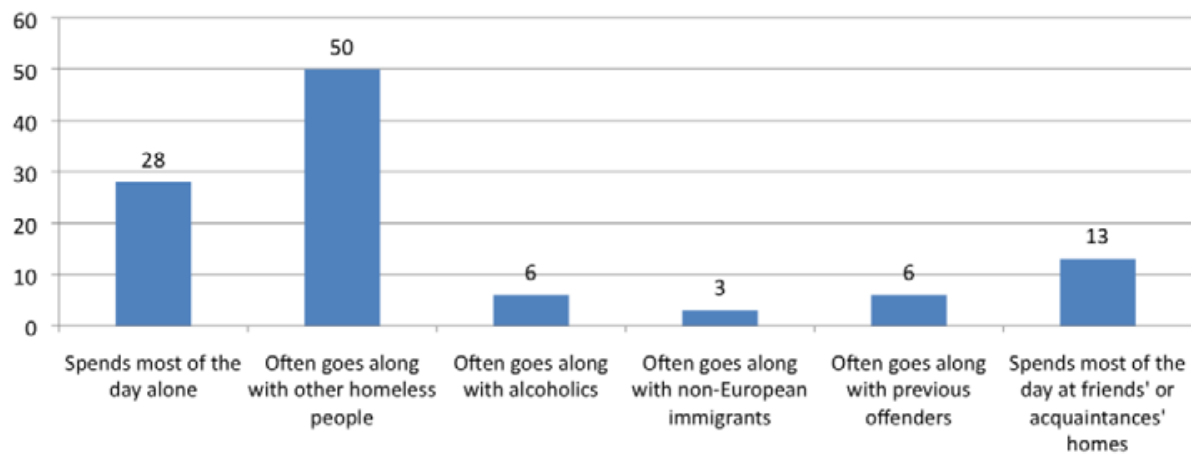

Figure 18: Distribution of the main relational habits.

\section{Distribution of personal attitudes and other relevant features}

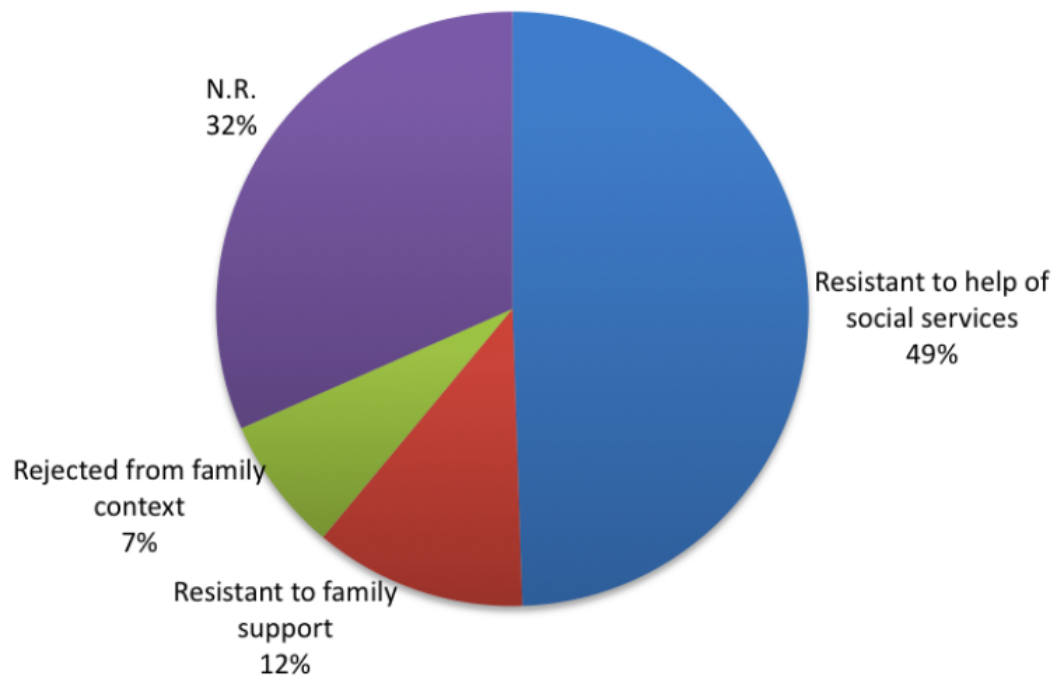

Figure 19: Distribution of personal attitudes and other relevant features.

\section{Distribution of judicial precedents as crime perpetrators or victims}

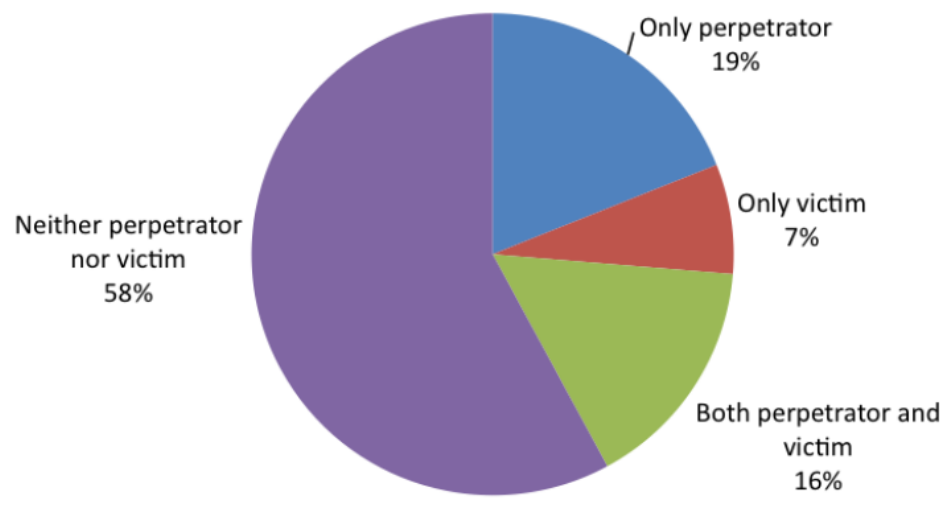

Figure 20: Distribution of judicial precedents as crime perpetrators or victims. 


\section{Distribution of judicial precedents as crime perpetrators or victims $\mathbf{X}$ gender}

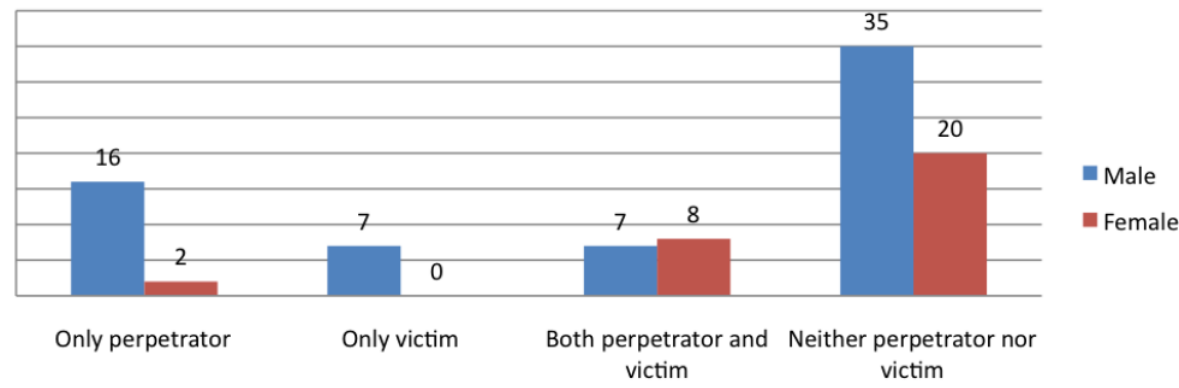

Figure 21: Distribution of judicial precedents as crime perpetrators or victims $\mathrm{X}$ gender.

\section{Distribution of the types of crimes perpetrated before the slide into homelessness $X$ gender}

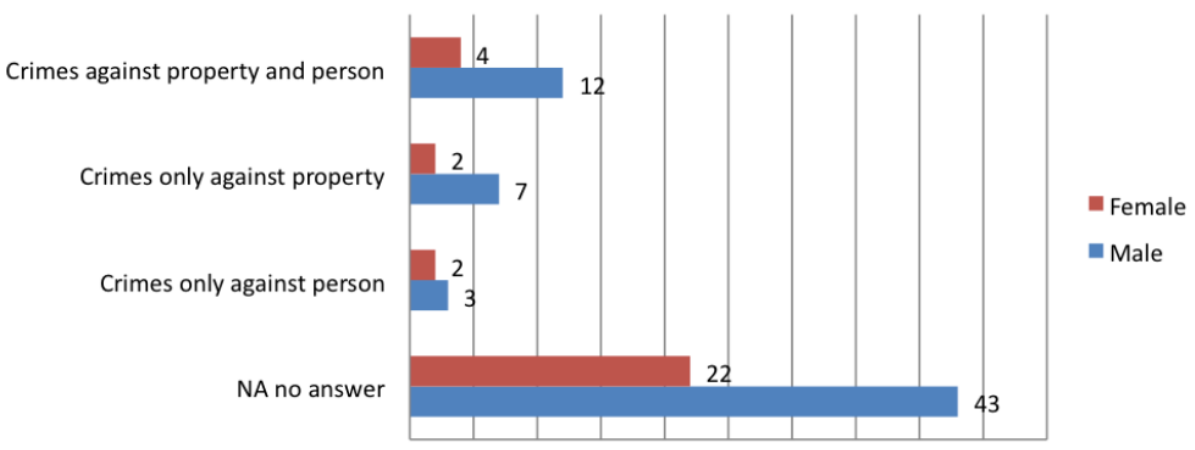

Figure 22: Distribution of the types of crimes perpetrated before the slide into homelessness $\mathrm{X}$ gender.

\section{Distribution of the types of crimes perpetrated after the slide into homelessness $\mathrm{X}$ gender}

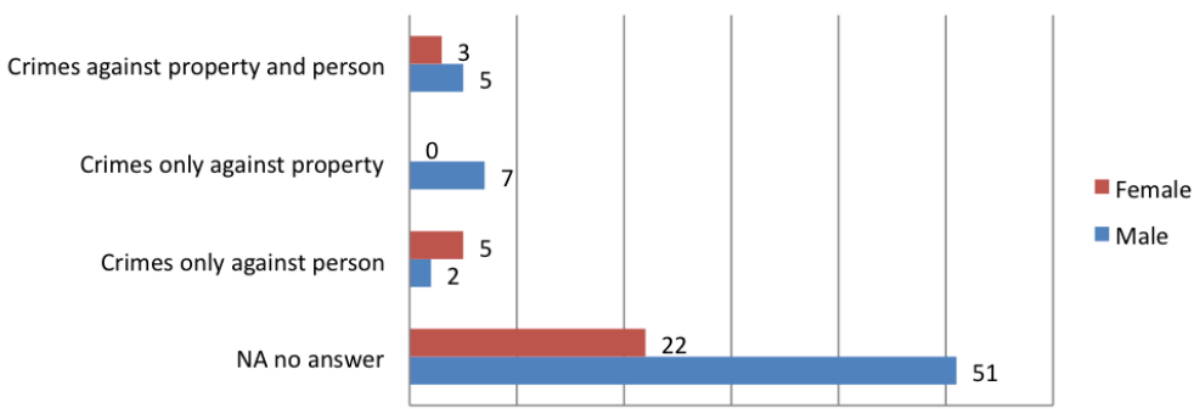

Figure 23: Distribution of the types of crimes perpetrated after the slide into homelessness.

was perpetrated (before or after the slide into homelessness, see Figures 22-24).

The results show that the tendency to commit crimes decreased after the slide into homelessness: only $17 \%$ of the cases over the total sample $(\mathrm{N}=95)$ underwent a relapse into crime after becoming a homeless, although we must consider that not all of the sample answer to this question $(65 \%$ did not provide an answer). The tendency to refrain from committing crimes after the slide into homelessness, although is a result which contrasts with those reported by the current literature, could be likely related to the heavy demands for personal adjustment and survival of living on the road. In fact, this condition requires homeless to limit their engagement with the police and to resort to street behavioral codes and rules. Therefore, the great difficulties of the local services and of the judicial 


\section{Distribution of answers to the item: "After the slide into homelessness, did you relapse into crime?"

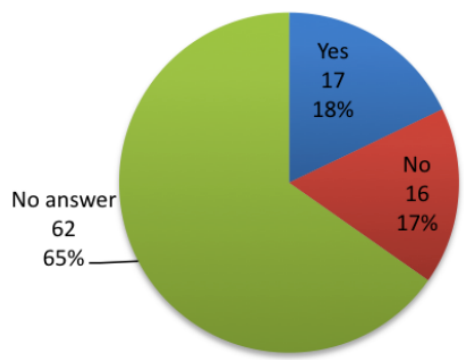

Figure 24: Distribution of answers to the item: "After the slide into homelessness, did you relapse into crime?"

authority to get in touch with the homeless, together with the intrinsic resistances and characteristics of these people, can lead to a global reduction of the number of crimes that can possibly be accounted for among the homeless. It is plausible that the incidence of crimes among this portion of the population is therefore underestimated.

With respect to the victims of the crimes they have perpetrated, most of the homeless report not knowing them (22 subjects over 95). A modest result has to do with the crimes perpetrated against family members or other homeless, which appear infrequent (13 subjects over 95) (Figure 25).

Among the crimes perpetrated against the homeless, those against the property and the person are the most frequent ones, both before and after the slide into homelessness: 17 subjects over 95 were reported before and 8 after slide into homelessness (Figures 27, 28). It must be considered that a consistent number of subjects refused to provide such

\section{Distribution of answers to the item: "When you were the perpetrator, who was the victim?"}

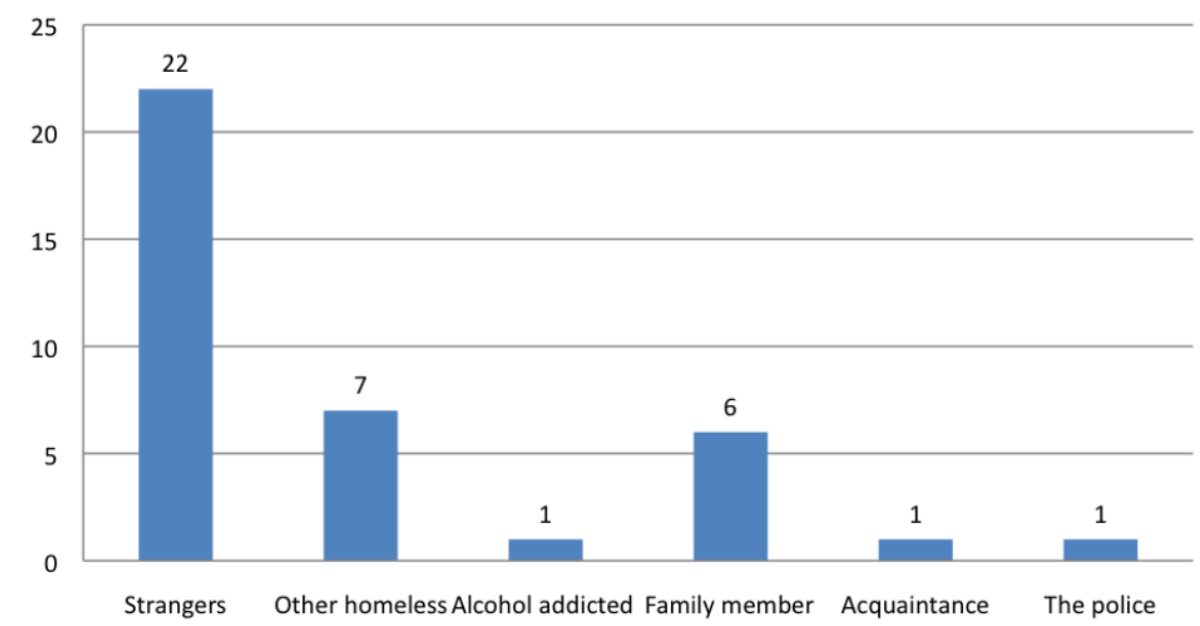

Figure 25: Distribution of answers to the item: "When you were the perpetrator, who was the victim?"

\section{The crime perpetrated was reported by:}

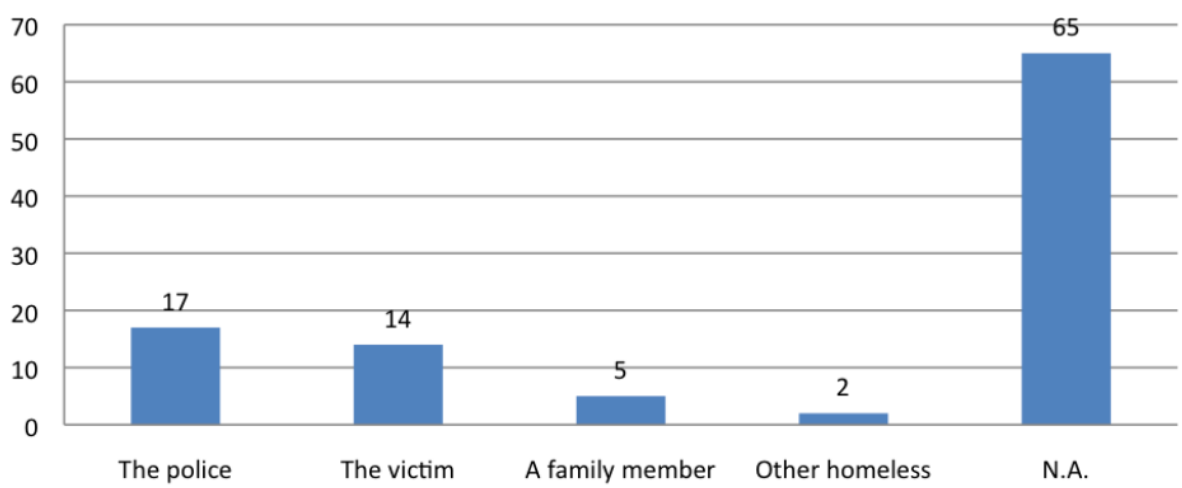

Figure 26: The crime perpetrated was reported by. 


\section{Distribution of the types of crimes sustained before the slide into homelessness}

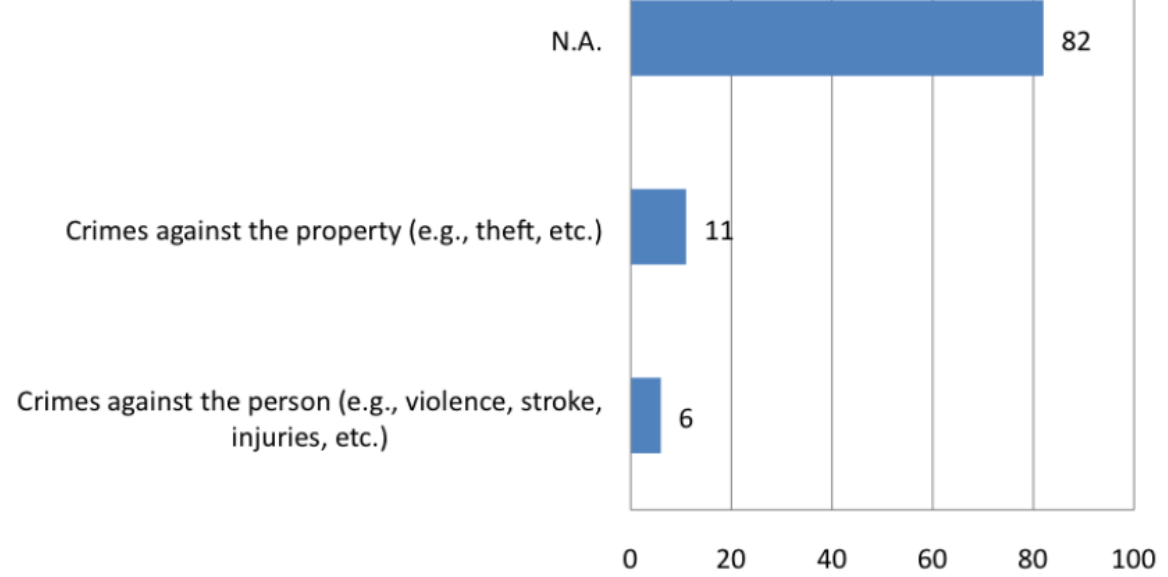

Figure 27: Distribution of the types of crimes sustained before the slide into homelessness.

\section{Distribution of the types of crimes sustained after the slide into homelessness}

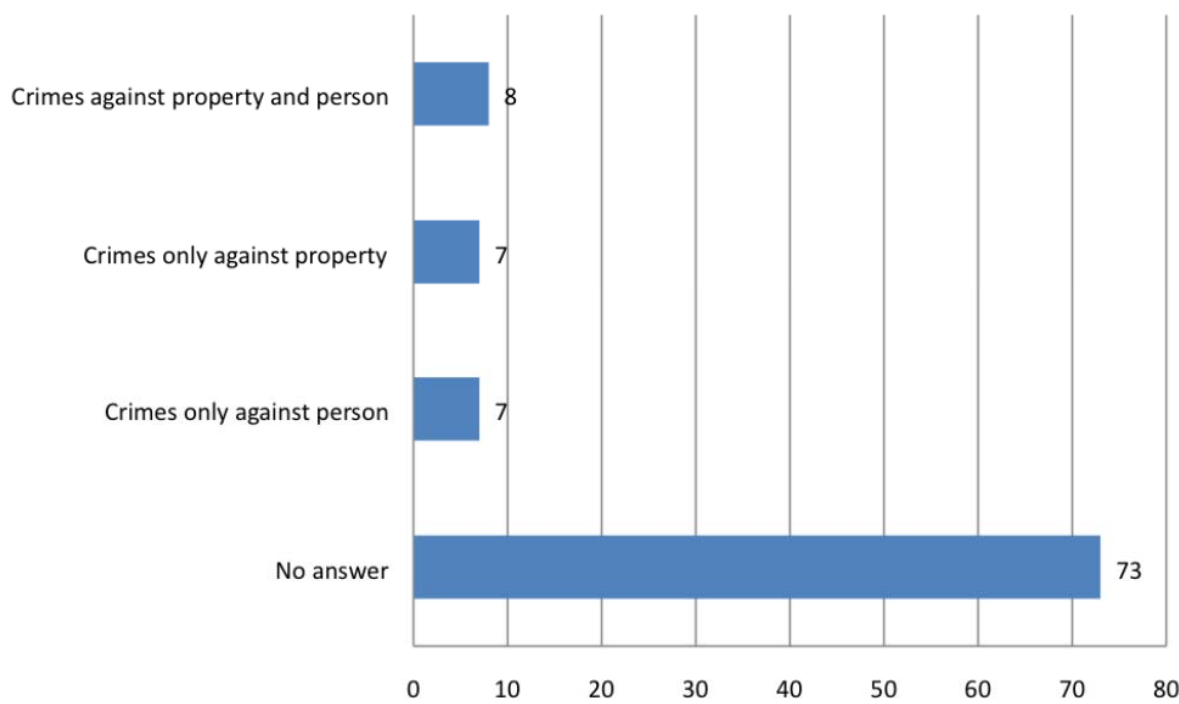

Figure 28: Distribution of the types of crimes sustained after the slide into homelessness.

information (before: 82 were not answering about before and 73 about after the slide into homelessness). The perpetrators of the crimes against the homeless were mainly other homeless, non-European immigrants or strangers (79\%) (Figures 29, 30).

\section{CONCLUSIONS}

In light of these preliminary findings from a larger ongoing study, notwithstanding the small sample size, we may suggest that even if the homeless are more likely during their lives to commit crimes and therefore to get involved with the criminal and judicial system, it is also true, on the other hand, that they represent one of the most vulnerable parts of the population, because they lack protection against the risk of being victims of crimes.

The relation between homelessness and crimes takes a circular shape: because the homeless live on the road, they are more exposed to perpetrate crimes, often to respond to the needs of subsistence and survival; nevertheless, at the same time, because they live in contexts with high rates of criminality, which lack defense and protection, they are also more exposed to become victims of different types of crimes. In conclusion, based on the literature reviewed above, as well as on our preliminary findings, it is important to 
Distribution of answers to the item: "As a victim, who perpetrated the crime against you, after the slide into

\section{homelessness?" (Percentages of a total of 22} individuals)

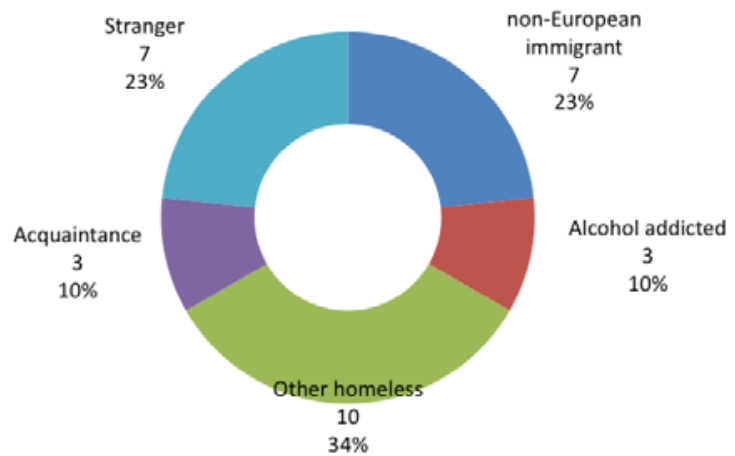

Figure 29: Distribution of answers to the item: "As a victim, who perpetrated the crime against you, after the slide into homelessness?" (Percentages of a total of 22 individuals).

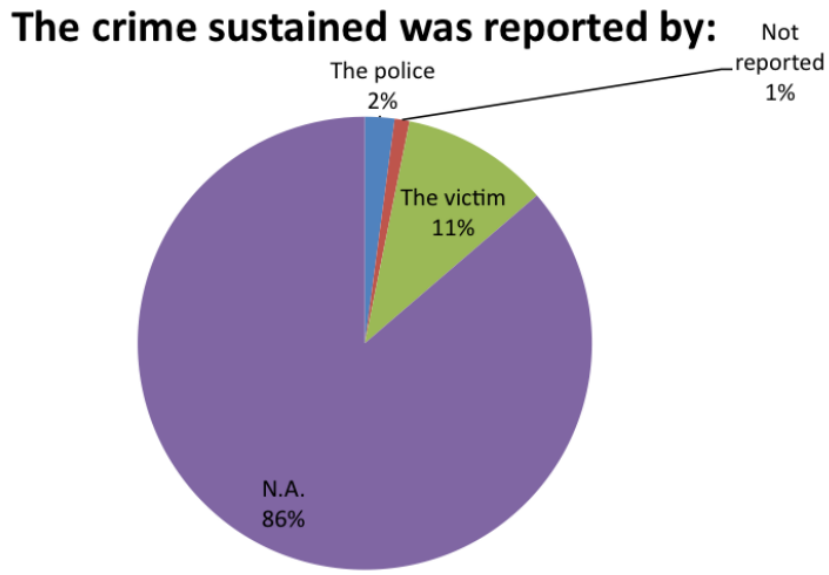

Figure 30: The crime sustained was reported by.

implement interventions that target homeless people. The aims of intervention programs should be the following:

- to support the homeless to get out of the contexts of severe social alienation, in which they spend their daily lives, and which appear characterized by high rates of crimes;

- to make the homeless less vulnerable to victimization perpetrated by others who live in their same conditions as well as from people living in normal conditions;

- to hinder the tendency of homelessness to become a chronic condition, as well as the estrangement from the self, caused by a prolonged condition of living on the road.

\section{REFERENCES}

Allgood, S., Moore, M. and Warren, R.S. Jr. 1997. "The duration of sheltered homelessness in a small city" Journal of Housing Research 6:60-80. http://dx.doi.org/10.1006/jhec.1997.0204

Ambrosio, E., Baker, D., Crowe, C., and Hardill, K. 1992. "The Street Health report: A study of the health care of homelessness, women, and men in the City of Toronto" Toronto: Street Health.

Anderson, N., 1923. "The Hobo: The Sociology of the Homeless Man" Chicago: University Of Chicago Press.

Ballintyne, S., 1999. "Unsafe Streets: Street homelessness and crime" London: Institute for Public Policy Research.

Bayatpour, M., Wells, R.D., and Holford, S. 1992. "Physical and sexual abuse as predictors of substance use and suicide among pregnant teenagers" Journal of Adolesc Health, 13: 128-132. http://dx.doi.org/10.1016/1054-139X(92)90079-Q

Bassuk, E.L., and Weinreb, L. 1993. "Homeless pregnant women: Two generations at risk" American Journal of Orthopsychiatry 63: 348-357. http://dx.doi.org/10.1037/h0085034

Beithman, J.H., Zucker, K.J., Hood, J.E., Da Costa, G.A., and Akman, D. 1991. "A review of the short-term effects of child sexual abuse" Child Abuse and Neglect 15: 537-556. http://dx.doi.org/10.1016/0145-2134(91)90038-F

Beithman, J.H., Zucker, K.J., Hood, J.E., Da Costa, G.A., Akman, D. and Cassavia, E. 1992. "A review of the long-term effects of child sexual abuse" Child Abuse and Neglect 16: 101-118. http://dx.doi.org/10.1016/0145-2134(92)90011-F

Bonadonna, F. 2005. "Il nome del barbone. Vite di strada e povertà estreme in Italia" [The name of the tramp: lifes on the road and extreme poverty in Italy]. DeriveApprodi: Roma.

Brassard, R., and Cousineau, M.M. 2000. "Victimisation et prise en charge des itinérants: entre aide et contrôle" in Laberge D. (a cura di): L'errance urbaine, Éditions Multimondes, Quebec.

Brown, A., and Finkelhor, D. 1986. "Impact of child sexual abuse: A review of the research" Psychological Bulettinl 99: 66-77. http://dx.doi.org/10.1037/0033-2909.99.1.66

Carpentier, C. 2002. "Drug Related Social Exclusion, in the Context of socio-demographic and Economic Indicators" Working paper. EMCDDA: Lisbon.

Chamberlain, C., and Mackenzie, D. 2003. "Counting the homeless 2001" Australian Bureau of Statistics.

Chamberlain, C., Johnson, G., and Theobald, J. 2007. "Homelessness in Melbourne: Confronting the Challenge" Melbourne: HomeGround Services, The Salvation Army Crisis Services and RMIT University.

Clarke, M., and Cooper, M. 2000. "Homeless Youth: Falling between the cracks: An investigation of youth homelessness in Calgary" Youth Alternative Housing Commitee.

CNCA 2005. "Sostanze senza dimora. Una ricerca condotta in servizi che accolgono persone consumatrici di sostanze $e$ in condizione di senza dimora" [Homeless substances. A research on the services hosting the substance consuming homeless people]. Comunità Edizioni.

Corbi, G., Grattagliano, I., Catanesi, R., Ferrara, N., Yorston, G., and Campobasso C.P. 2012 "Elderly Residents at Risk for Being Victims or Offenders" Journal of the American Medical Directors Association, 13 (7):657-659. http://dx.doi.org/10.1016/j.jamda.2012.05.012

D'ercole, A., and Struening, E. 1990. "Victimization among homeless women: Implications for service delivery" Journal of Community Psychology, 18:141-151. http://dx.doi.org/10.1002/1520-6629(199004)18:2<141::AIDJCOP2290180206>3.0.CO;2-O 
Eberle, M., Kraus, D., Serge, L., and Hulchanski, D. 2001. "Homeless - causes and effects: The relationship between homelessness and the health, Social Services and Criminal Justice Systems: A review of Literature" British Columbia, 1.

FEANTSA 2005, by Edgard, B., and Meert, H., "Fourth review of Statistics on Homelessness in Europe" The ETHOS definition of Homelessness. European Observatory on Homelessness Fourth Review of Statistics on Homelessness in Europe.

Fichter, M.M., Koniarczyk, M., Greifenhagen, A., Koegel, P., Quadflieg, N., Wittchen, H.U., and Wolz J. 1996. "Mental illness in a representative sample of homeless men in Munich, Germany" European Archives of Psychiatry and Clinical Neuroscencei 246: 185-196. http://dx.doi.org/10.1007/BF02188952

Fichter, M.M., and Quadflieg, N. 2001. "Prevalence of mental illness in homeless men in Munich, Germany: results from a representative sample" Acta Psychiatrica Scandinavica 103: 94-104.

http://dx.doi.org/10.1034/j.1600-0447.2001.00217.x

Fisher, P.J. 1992. "Criminal behaviour and victimization among homeless people" in Janiel, R.I. (edited by): Homelessness, a prevention-oriented approach. The Johns Hopkins University Press, New York.

Fisher, S.N., Shinn, M., Shrout, P., and Tsemberis, S. 2008. "Homelessness, mental illness and criminal activity: examining patterns over time" American Journal of Community Psychology 45: 251-265. http://dx.doi.org/10.1007/s10464-008-9210-z

Gaetz, S. 2004. "Understanding Research on Homelessness in Toronto: A Literature Review". York University and Wellesley Central Health Foundation, Toronto.

Gardiner, H., and Cairns K.V. 2002. "2002 Calgary Homelessness Study: Final Report "(October 2002). Research Report to the Calgary Homeless Foundation. Calgary: Calgary Homeless Foundation.

Grattagliano, I., Cassibba, R., Greco, R., Laudisa, A., Torres, A., and Mastromarino, A., 2012. "Stalking: Old behaviour new crime. Reflections on 11 cases assessed in the judicial district of Bari" Rivista di Psichiatria 47, (1): 65-72.

Grattagliano, I., 2013. "Pas e metodologia peritale" Psicologia Clinica dello Sviluppo 17(2): 340-344.

Greco, R., Curci, A., and Grattagliano, I., (2009). "Juvenile Criminality: General Strain Theory and the reactive-proactive aggression trait" Rivista di Psichiatria, 44 (5): 328-336.

Greene, J.M., Ennett, S.T., and Ringwalt, C.L. (1999). "Prevalence and correlates of servival sex among runaway and homeless youth" Am J Public Health, 89(9):1406-1409. http://dx.doi.org/10.2105/AJPH.89.9.1406

Herrman, H., Mcgorry, P., Bennett, P., Van Riel, R., and Singh, B. 1989. "Prevalence of severe mental disorders in disaffiliated and homeless people in inner Melbourne" The American Journal of Psychiatry 146:1179-1184. http://dx.doi.org/10.1176/ajp.146.9.1179

Hermen, D.B., Susser, E.S., Struening, E. L., and Link, B. L. 1997. "Adverse childhood experiences: Are they risk factors for adult homelessness?" American Journal of Public Health, 87:249-255.

http://dx.doi.org/10.2105/AJPH.87.2.249

Hewitt, J.A. 1994. "Technical Report: Homelessness and the Criminal Justice System in Canada: A literary review" Department of Justice, Government of Canada, Canada.

Hwang, S.W. 2000. "Mortality among men using homeless shelters in Toronto, Ontario" Journal of the American Medical Association 283:2152-2157. http://dx.doi.org/10.1001/jama.283.16.2152

IPRES 2013. Relazione sociale 2012. Ambito di Bari [Social report. The area of Bari].

Istat 2012. Le persone senza dimora [The homeless].
Janus, M., Mccormack, A., Bugess, A.W., and Hatman, C. 1987. Adolescent runaways: Causes and consequences. Lexington Books, Lexington, MA.

Koegel, P., Burnam, M.A., and Farr, R.K. 1988. "The prevalence of specific psychiatric disorders among homeless individuals in the inner city of Los Angeles" Archives General Psychiatry, 45:1085-1092. http://dx.doi.org/10.1001/archpsyc. 1988.01800360033005

Kushel, M.B., Evans, J.L., Perry, S., Robertson, M.J., and Moss, A.R. 2003. "No door to lock: Victimization among homeless and marginally housed persons" Archives of Internal Medicine, 10:2492-2499. http://dx.doi.org/10.1001/archinte.163.20.2492

Laberge, D. 2000. "L'erraire urbaine: collectif de recherché sur L'itinérance, la pauvreté et l'exclusion sociale" Les Editions Multimondes, Sainte-Foy.

Lisi, A., Stallone, V., Tomasino, M.G., Affatati, V., Zelano, C., and Grattagliano, I. 2012, "The utility and limitations of the Human Figure Drawing Test in the evaluation of the child abuse's cases in expert testimony circles" Psicologia .Clinica dello. Sviluppo. 16 (2):421-439

Lisi, A., Stallone, V., Tomasino, M.G., Affatati, V., Dimastromatteo, C., and Grattagliano, I. 2013, "Uselfulness and limits of the Family drawing test, in the evaluation of child sexual abuse in expert testimony: A field survey" Maltrattamento ed Abuso all'Infanzia, 15 (1):81.96

Levin, J., and Mcdevitt, J. 1999. "Hate crimes" in Kurtz L.R., Turpin J.E. (edited by): Encyclopedia of violence, peace, and conflict. Academic Press, Oxford

London, J., 1907, The road; trad. it. di Maggiani, M., 1997, La strada, Torino, Einaudi.

Margari, L., Pinto, F., Lafortezza, M.E., Craig, F., Grattagliano, I., Zagaria, G., and Margari, F. 2013. "Mental health in migrant schoolchildren in Italy: Teacher-reported behavior and emotional problems" Neuropsychiatric disease and treatment. 9:231-241.

http://dx.doi.org/10.2147/NDT.S37829

Martell, D.A., Rosner, R., and Harmon, R.B. 1995. "Base-rate estimates of criminal behavior by homeless mentally ill persons in New York City" Psychiatric Services 46:596-601. http://dx.doi.org/10.1176/ps.46.6.596

Martell, D.A. 1991. "Homeless mentally ill offenders and violent crimes" Law and Human Behavior 15:333-347. http://dx.doi.org/10.1007/BF02074075

Mccarthy, B., and Hagan, J. 1991. "Homelessness: A criminogenic situation?" British Journal of Criminology, 31: 393-410.

MacKenzie, D., and Chamberlain, C. 2003. "Homelessness career. Pathways in and out of homelessness" Melbourne, Swinburn and RMIT Universities.

Mcniel, D.E., Binder, R.L, and Robinson, J.A. 2005. "Incarceration associated with homelessness, mental disorder and cooccurring substance abuse" Psychiatric Services, 56 (7), 840-846.

http://dx.doi.org/10.1176/appi.ps.56.7.840

Marvelli, E, Grattagliano, I, Aventagiato, L, Gagliano-Candela R, 2013. "Substance use and victimization in violent assaults" Clinica Terapeutica, 164(3):239-244.

Mental Health Policy Research Group 1998. "Mental illness and pathways into homelessness: proceedings and recommendations" Toronto.

Meo, A. 1995. "I senza casa a Torino. Vita quotidiana e percorsi biografici nel tessuto urbano" [The homeless in Turin: Daily life and biographic pathways in the city]. Universiy of Trento.

Metraux, S., and Culhane, D. 2004. "Homeless shelter use and reincarceration following prison release" Criminology and Public Policy, 3(2), 139-160. http://dx.doi.org/10.1111/j.1745-9133.2004.tb00031.x 
Murray, S. 2009. "Somewhere safe to call home. Violence Against Women During Homelessness" Centre for Applied Social Research, RMIT University.

Nanni, W. 1998. "Persone senza fissa dimora e povertà estreme: aspetti quantitativi e qualitativi del fenomeno" [The homeless and extreme poverty: quantitative and qualitative aspects of the phenomenon]. In Caritas Italiana, Fondazione E. Zancan (a cura di), Gli ultimi della fila. Rapporto 1997 sui bisogni dimenticati [The lasts of the row. Report 1997. The forgotten needs]. Feltrinelli, Milano, p. 80.

Novac, S. 2007. "Family violence and homelessness: Connections and dynamics" Centre for Urban and Community Studies, Research Bullettin n. 40.

Novac, S., Brown, J., and Bourbonnais, C. 1996. "No Room of Her Own: A Literature Review on Women and Homelessnes" Canada Mortgage and Housing Corporation, Ottawa.

North, C.S., Smith, E.M., and Spitznagel, E.L. 1994. "Violence and the homeless: An epidemiologic study of victimization and aggression" J Trauma Stress, 7:95-110. http://dx.doi.org/10.1002/jts.2490070110

Parkinson, S. 2004. "Getting My Life Back Together: Women, Housing and Multiple Needs" Hanover Welfare Services, Melbourne.

Patterson, G.R., Dishion, T.J., and Bank, L. 1984. "Family interaction: A process model of deviancy training" Aggressive Behavior, 10:253-267.

http://dx.doi.org/10.1002/1098-2337(1984)10:3<253::AIDAB2480100309>3.0.CO;2-2

Patterson, G.R., Debaryshe, B.D., and Ramsey, E. 1989. "A developmental perspective on antisocial behavior" American Psychologist 44:329-335. http://dx.doi.org/10.1037/0003-066X.44.2.329

Richman, B.J., Convit, A., and Martell, D. 1992. Homelessness and the mentally ill offender, Journal of Forensic Science, 37: 932-937.

Scorca, A., Santoro, V., De Donno, A., Grattagliano, I., Tafuri, S., and Introna, F. 2013. "Early childhood caries (ECC) and neglect in child care: Analysis of an Italian sample" Clinica Terapeutica. 164 (5):e365-e371

Shapcott, M. 2007. "Physical and Sexual Violence Rates For Homeless Many Times Higher Than Housed" Wellesley Institute, Toronto.

Simons, R.L., Whitbeck, L.B., and Bales, A. 1989. "Life on the streets: Victimization and psychological distress among the adult homeless" Journal of Interpersonal Violence, 4: 482501.

http://dx.doi.org/10.1177/088626089004004007
Smith, E.M., North, C.S., and Spitznagel, E.L. 1993. "Alcohol, Drugs, and Psychiatric Comorbidity Among Homeless Women: An Epidemiologic Study" Journal of Clinical Psychiatry, 54:8287.

Solarino, B., Grattagliano, I., Catanesi, R., and Tsokos, M. 2012. "Child starvation and neglect: A report of two fatal cases" Journal of Forensic and Legal Medicine, 19 (3):171-174. http://dx.doi.org/10.1016/j.jflm.2011.10.004

Shelter Cymru, S. 2004. "Homelessness it's a crime, the impact and costs of a failing system" Swansea, Wales.

Snow, D.A., Baker, S.G., and Anderson, L. 1989. "Criminality and homeless men: An empirical assessment" Social Problems, 36:532-549. http://dx.doi.org/10.2307/3096817

Stermac, L., and Paradis, E.K. 2001. "Homeless women and victimization: Abuse and mental health history among homeless rape survivors" Resources for Feminist Research/Documentation sur la Recherche Feministe, 28:6580.

Tanner, J., and Wortley, S. 2002. "The Toronto youth crime and victimization study: Overview report" Centre for Criminology University of Toronto, Toronto.

Tyler, K.A., Hoyt, D.R., and Whitbeck, L.B. 2000. "The Effects of Early Sexual Abuse on Later Sexual Victimization Among Female Homeless and Runaway Adolescents" Journal of Interpersonal Violence 15(3), 235-250. http://dx.doi.org/10.1177/088626000015003001

Wachholz, S. 2005. "Hate crimes against the homeless: Warning-out New England style" Journal of Sociology and Social Welfare, 32:141-163.

Vazquez, C., Munoz, M., and Sanz, J. 1997. "Lifetime and 12-month prevalence of DSM-III-R mental disorders among the homeless in Madrid: a European study using the CIDI" Acta Psychiatrica Scandinavica, 95: 523-530. http://dx.doi.org/10.1111/j.1600-0447.1997.tb10141.x

Wenzel, S.L., Leake, B. D., and Gelberg, L. 2001. "Risk factors for major violence among homeless women" Journal of Interpersonal Violence, 16, 739-752. http://dx.doi.org/10.1177/088626001016008001

Whitbeck, L.B., Hoyt, D.R., and Yoder, K. 1999. "A risk-amplification model of victimization and depressive symptoms among runaway and homeless adolescents" American Journal of Community Psychology, 27: 273-296. http://dx.doi.org/10.1023/A:1022891802943

Zorzi, R., Scott, S., Doherty, D., Engman, A., Lauzon, C., Mcguire, M., Et al. 2006. "Housing Options Upon Discharge from Correctional Facilities" Cathexis Consulting Inc., Toronto.

\section{DOI: http://dx.doi.org/10.6000/1929-4409.2015.04.08}

(c) 2015 Grattagliano et al.; Licensee Lifescience Global.

This is an open access article licensed under the terms of the Creative Commons Attribution Non-Commercial License (http://creativecommons.org/licenses/by-nc/3.0/) which permits unrestricted, non-commercial use, distribution and reproduction in any medium, provided the work is properly cited. 